\title{
ANALISIS KANDUNGAN LIMBAH INDUSTRI TAHU DAN TEMPE RAHAYU DI KELURAHAN UNER KECAMATAN KAWANGKOAN KABUPATEN MINAHASA
}

\author{
Febrian Sayow \\ Bobby Vian Jhon Polii \\ Wenny Tilaar \\ Kojoh Deanne Augustine
}

\begin{tabular}{ll}
\hline Naskah diterima melalui E-mail Jurnal Ilmiah agrisosioekonomi@ unsrat.ac.id & : Jumat, 22 Mei 2020 \\
Disetujui diterbitkan & : Jumat, 29 Mei 2020 \\
\hline
\end{tabular}

\begin{abstract}
This study aims to (1). Knowing the content and quality of Rahayu's tofu and tempe factory liquidwaste in Uner Village, Kawangkoan Sub-district, Minahasa Regency, and (2). To find out whether Rahayu's tofu and tempe factory liquid waste has exceeded the quality standard. This research was conducted for 3 months, namely in January 2020-March 2020. Sampling locations were carried out in the factory of Tahu and Tempe Rahayu Sub-district in Uner Village, Kawangkoan District, then continued with the analysis at the Manado Industrial Research and Standardization Laboratory (Baristand). This research was a descriptive research and laboratory analysis. Waste water sampling was carried out using a composite sampling method. Sampling was done in the first two places, raw water is used to make tofu and tempe in an inlet and the first was taken from the tofu factory wastewater and tempe in the sewer. Waste liquid sampling was carried out 3 times and for analysis carried out at the Baristand Laboratory to obtain data according to the parameters set in this study. The results showed that the quality of Rahayu tofu and tempe industrial liquid waste based on the analysis of BOD, COD, and TSS parameters that have been analyzed accordingly and have not passed the quality standards set by the Government. However, for the pH parameters are not appropriate and in accordance with the quality standards set by Government. ${ }^{*}$ eprm*
\end{abstract}

Keywords: tofu and tempeh industry, analysis, liquid waste content, Minahasa Regency

\begin{abstract}
ABSTRAK
Penelitian ini bertujuan untuk (1). Mengetahui kandungan limbah pabrik tahu dan tempe Rahayu yang ada Kelurahan Uner Kecamatan Kawangkoan Kabupaten Minahasa, serta (2). Untuk mengetahui apakah limbah pabrik tahu dan tempe Rahayu sudah melebihi baku mutu. Penelitian ini dilaksakan selama 3 bulan yaitu pada bulan Januari 2020- Maret 2020. Lokasi pengambilan sampel di lakukan di Pabkrik Tahu dan Tempe Rahayu di Kelurahan Uner Kecamatan Kawangkoan, kemudian dilanjutkan analisis di Laboratorium Balai Riset dan Standardisasi Industri (Baristand) Manado. Penelitian ini merupakan penelitian deskriptif dan analisi lab. Pengambilan contoh air limbah di lakukan dengan metode composite sampling. Pengambilan sampel dilakukan di dua tempat pertama diambil air baku yang digunakan untuk pembuatan tahu dan tempe di bak penampungan air (inlet) dan yang kedua diambil air limbah pabrik tahu dan tempe pada saluran pembuangan air limbah. Pengambilan sampel air limbah dilakukan sebanyak 3 kali dan untuk analisis di lakukan di Laboratorium Baristand untuk mendapatkan data sesuai parameter yang telah ditetapkan dalam penelitian ini. Hasil penelitian menunjukkan Kulitas limbah cair industri tahu dan tempe Rahayu berdasarkan analisis parameter BOD, COD, dan TSS yang telah dianalisis adalah sesuai dan belum melewati baku mutu yang sudah di tetapkan oleh Pemerintah sedangkan untuk parameter $\mathrm{pH}$ tidak sesuai dan sudah melewati baku mutu yang di tetapkan oleh Pemerintah. "eprm*
\end{abstract}

Kata kunci : analisis, kandungan limbah, industri tahu dan tempe, Kabupaten Minahasa 


\section{PENDAHULUAN}

\section{Latar Belakang}

Tahu dan tempe merupakan makanan yang digemari masyarakat, baik masyarakat kalangan bawah hingga atas. Keberadaannya sudah lama diakui sebagai makanan yang sehat, bergizi dan harganya murah. Hampir di tiap kota di Indonesia dijumpai industri tahu dan tempe. Umumnya industri tahu dan tempe termasuk ke dalam industri kecil yang dikelola oleh rakyat dan beberapa diantaranya masuk dalam wadah Koperasi Pengusaha Tahu dan Tempe (KOPTI). Proses pembuatan tahu dan tempe masih sangat tradisional dan banyak memakai tenaga manusia. Perkembangan industri dewasa ini sangat pesat, terutama industri rumah tangga yang sangat membantu dalam menunjang kehidupan masyarakat. Industri rumah tangga termasuk dalam penggolongan industri kecil. Industri kecil seperti industri pembuatan tahu banyak berkembang di pedesaan dan perkotaan. Umumnya industri kecil memiliki peralatan dan pengolahan yang sederhana. Sayangnya ditinjau dari segi lingkungan, berkembangnya industri kecil pada tingkat rumah tangga sangat membahayakan kehidupan masyarakat, karena setiap industri rumah tangga ternyata tidak memperhatikan tata letak pabrik maupun sistem pembuangan limbah (Yahya, 2016). Limbah dari pengolahan tahu dan tempe mempunyai kadar BOD sekitar 5.000 $10.000 \mathrm{mg} / \mathrm{l}$, COD 7.000 - $12.000 \mathrm{mg} / \mathrm{l}$. Limbah tempe dengan kandungan protein merupakan salah satu limbah yang masih memiliki nilai ekonomis, karena kandungan senyawa organik dan nutrient yang terdapat di dalamnya masih relative tinggi jika dibandingkan dengan yeast extract. Pemanfaatan limbah cair tempe dari proses perebusan dan perendaman dapat dibuat sebagai pupuk cair. Pupuk cair berisi bakteri yang bermanfaat untuk menyuburkan tanah dan tanaman. Peran bakteri bermanfaat dalam pupuk cair ini adalah mengikat nitrogen $(\mathrm{N})$, fosfor $(\mathrm{P})$, Kalium (K) dan unsur lain untuk kebutuhan tanaman, sehingga dapat meningkatkan produktivitas tanaman. Sedangkan limbah cair dari pencucian dapat di daur ulang kembali untuk perebusan dan perendaman dengan teknologi tepat guna dapat mengurangi pencemaran limbah tempe terutama kandungan DO, Zat Organic dan NH3 (Lilis, 2008).
Limbah industri tahu dan tempe dapat berupa limbah padat maupun limbah cair. Limbah padat dihasilkan dari proses penyaringan dan penggumpalan, limbah ini kebanyakan dijual dan diolah menjadi tempe gembus dan pakan ternak. Sedangkan limbah cairnya dihasilkan dari proses pencucian, perebusan, pengepresan dan pencetaka $\mathrm{n}$ tahu, oleh karena itu limbah cair yang dihasilkan dari industri tahu dan tempe volumenya cukup tinggi. Limbah cair tahu tempe dengan karakteristik mengandung bahan organik tinggi dan kadar BOD, COD yang cukup tinggi pula, jika langsung dibuang ke badan air, maka akan menurunkan daya dukung lingkungan pada perairan tersebut (Agung dan Hanry,2013)

Menurut Peraturan Menteri Lingkungan Hidup Republik Indonesia No.5 Tahun 2014 Tentang Baku Mutu Air Limbah, Baku Mutu Air Limbah Bagi Usaha Dan/Atau Kegiatan Pengolahan Kedelai. Indikator pencemar bahan organik ditandai oleh parameter BOD, COD, TSS, dan pH. Pabrik tahu dan tempe Rahayu yang berada di Kelurahan Uner Kecamatan Kawangkoan berdiri pada tahun 2004, pasokan bahan baku berupa kedelai diperoleh dari gudang penampungan yang ada di Kota Manado yang di impor dari Amerika. Kedelai yang dgunakan dalam pembuatan tahu dan tempe di pabrik ini berbeda untuk pembuatan tahu kedelai yang digunakan $350 \mathrm{~kg}$ per hari sedangkan untuk pembuatan tempe kedelai yang digunakan $40 \mathrm{~kg}$ per hari. Untuk penggunan air dalam proses pembuatan tahu dan tempe di pabrik in \pm 100 liter air. Dalam industri pembuatan tahu dan tempe dihasilkan limbah, baik limbah padat maupun limbah cair, di pabrik ini limbah padatnya dibeli oleh para peternak untuk di buat makanan ternak sedangkan untuk limbah cairnya langsung di buang ke saluran pembuangan dan di pabrik ini limbah cairnya belum diolah dengan baik. Penelitian tentang analisis kandungan limbah cair di pabrik tahu dan tempe Rahayu belum pernah dilakukan, jadi penting adanya dilakukan penelitian agar bisa mengetahui kandungan limbah di pabrik tersebut.

\section{Proses Pembuatan dan Karkteristik Limbah Pabrik Tahu dan Tempe}

\section{Proses Pembuatan Tahu}

Tahu dan tempe merupakan salah satu jenis makanan sumber protein dengan bahan dasar kacang kedelai yang sangat digemari oleh masyarakat Indonesia. Sebagian besar produk tahu di Indonesia dihasilkan oleh industri skala kecil yang kebanyakan terdapat di Pulau Jawa. Industri tersebut berkembang pesat sejalan dengan 
peningkatan jumlah penduduk. Namun, di sisi lain industri ini menghasilakan limbah cair yang berpotensi mencemari lingkungan. Industri tahu membutuhkan air untuk pemrosesannya, yaitu untuk prosees sortasi, peredaman, pengupasan kulit, pencucian, penggilingan, perebusan dan penyaringan. Pembuatan tahu pada prinsipnya dibuat dengan mengekstrak protein, kemudian mengumpulkannya, sehingga terbentuk padatan protein. Cara penggumpalan susu kedelai umumnya dilakukan dengan cara penambahan bahan penggumpal berupa asam. Bahan penggumpal yang biasa digunakan adalah asam cuka $(\mathrm{CH} 3 \mathrm{COOH})$, batu tahu $(\mathrm{CaSO} 4 \mathrm{nH} 2 \mathrm{O})$ dan larutan bibit tahu (larutan perasan tahu yang telah diendapkan satu malam).

Secara umum tahapan proses pembuatan tahu adalah sebagai berikut :

1. Kedelai yang telah dipilih dibersihkan dan disortasi. Pembersihan dilakukan dengan ditampi atau menggunakan alat pembersih.

2. Perendaman dalam air bersih agar kedelai dapat mengembang dan cukup lunak untuk digiling. Lama perendaman berkisar $4-10$ jam.

3. Pencucian dengan air bersih. Jumlah air yang digunakan tergantung pada besarnya atau jumlah kedelai yang digunakan.

4. Penggilingan kedelai menjadi bubur kedelai dengan mesin giling. Untuk memperlancar penggilingan perlu ditambahkan air dengan jumlah yang sebanding dengan jumlah kedelai.

5. Pemasakan kedelai dilakukan di atas tungku dan dididihkan selama 5 menit. Selama pemasakan ini dijaga agar tidak berbuih, dengan cara menambahkan air dan diaduk.

6. Penyaringan bubur kedelai dilakukan dengan kain penyaring. Ampas yang diperoleh diperas dan dibilas dengan air hangat. Jumlah ampas basah kurang lebih $70 \%$ sampai $90 \%$ dari bobot kering kedelai.

7. Setelah itu dilakukan penggumpalan dengan menggunakan air asam, pada suhu $50 \mathrm{oC}$, kemudian didiamkan sampai terbentuk gumpalan besar. Selanjutnya air di atas endapan dibuang dan sebagian digunakan untuk proses penggumpalan kembali.

8. Langkah terakhir adalah pengepresan dan pencetakan yang dilapisi dengan kain penyaring sampai padat. Setelah air tinggal sedikit, maka cetakan dibuka dan dianginanginkan, (Anonim, 2017).

\section{Proses Pembuatan Tempe}

Tempe merupakan hasil fermentasi kedelai, dan secara garis besar urutan proses pembuatan tempe adalan sebagai berikut :

- Kedelai dimasak, setelah masak kedelai direndam 1 malam hingga lunak dan terasa berlendir, kemudian kedelai dicuci hingga bersih.

- Kedelai dipecah dengan mesin pemecah, hingga kedelai terbelah dua dan kulit kedelai terpisah.

- Kulit kedelai dipisahkan dengan cara hasil pemecahan kedelai dimasukkan ke dalam air, sehingga kulit kedelai mengambang dan dapat dipisahkan.

- Kedelai kupas dicuci kembali hingga bersih, kemudian peragian dengan cara kedelai dicampurkan ragi yang telah dilarutkan dan didiamkan selama lebih kurang 10 menit.

- Kedelai yang telah mengandung ragi ditiriskan hingga hampir kering, kemudian dibungkus dengan daun pisang. Setelah fermentasi selama 2 hari diperoleh tempe.

\section{Karakteristik Air Limbah Industri Tahu}

Secara umum karakteristik air buangan dapat digolongkan atas sifat fisika, kimia, dan biologi. Akan tetapi, air buangan industri biasanya hanya terdiri dari karakteristik fisika dan kimia. Parameter yang digunakan untuk menunjukkan karakter air buangan industri tahu adalah (Kaswinarni, 2007):

1. Parameter fisika, seperti kekeruhan, suhu, zat padat, bau dan lain-lain.

2. Parameter kimia, dibedakan atas kimia organik dan kimia anorganik. Kandungan organik (BOD, COD, TOC) oksigen terlarut (DO), minyak atau lemak, nitrogen total, dan lain-lain. Sedangkan kimia anorganik meliputi: $\mathrm{pH}, \mathrm{Pb}, \mathrm{Ca}, \mathrm{Fe}, \mathrm{Cu}, \mathrm{Na}$, sulfur, dan lain-lain.

Beberapa karakteristik limbah cair industri tahu yang penting antara lain:

\section{Total Suspended Solid (TSS)}

TSS atau padatan tersuspensi Yaitu bahanbahan yang melayang dan tidak larut dalam air. Padatan tersuspensi sangat berhubungan erat dengan tingkat kekeruhan air. Kekeruhan menggambarkan sifat optik air yang ditentukan berdasarkan banyaknya cahaya yang diserap dan dipancarkan oleh bahan-bahan yang terdapat di dalam air. Kekeruhan disebabkan oleh adanya bahan organik dan anorganik yang tersuspensi dan terlarut. 
Semakin tinggi kandungan bahan tersuspensi tersebut, maka air semakin keruh (Effendi, 2003).

2. Biological Oxygen Demand (BOD)

BOD merupakan parameter yang digunakan untuk menilai jumlah zat organik yang terlarut serta menunjukkan jumlah oksigen yang diperlukan oleh aktivitas mikroba dalam menguraikan zat organik secara biologis didalam air limbah (MetCalf and Eddy. 2003). Air Limbah industri tahu mengandung bahan-bahan organik terlarut yang tinggi.

3. Chemical Oxygen Demand (COD)

Chemical Oxygen Demand (COD) atau kebutuhan oksigen kimia adalah sejumlah oksigen yang dibutuhkan agar bahan buangan yang ada dalam air dapat teroksidasi melalui reaksi kimia (MetCalf and Eddy. 2003). Jika kandungan senyawa organik dan anorganik cukup besar, maka oksigen terlarut di dalam air dapat mencapai nol sehingga tumbuhan air, ikan-ikan dan hewan air lainnya yang membutuhkan oksigen tidak memungkinkan hidup.

\section{Nitrogen Total (N-Total)}

Nitrogen organik dan nitrogen amonia dapat ditentukan secara atlantik menggunakan metode Kjeldahl, sehingga lebih lanjut konsentrasi keduanya dapat dinyatakan sebagai Total Kjeldahl Nitrogen (TKN). Senyawa-senyawa N-Total adalah senyawasenyawa yang mudah terkonversi menjadi amonium (NH4+) melalui aksi mikroorganisme dalam lingkungan air atau tanah (MetCalf dan Eddy, 2003). 5. Derajat Keasaman $(\mathrm{pH})$

Air limbah indutri tahu sifatnya cenderung asam, pada keadaan asam ini akan terlepas zat-zat yang mudah untuk menguap. Hal ini mengakibatkan limbah cair industri tahu mengeluarkan bau busuk. $\mathrm{pH}$ sangat berpengaruh dalam proses pengolahan air limbah. Baku mutu yang ditetapkan sebesar 6-9. Pengaruh yang terjadi apabila $\mathrm{pH}$ terlalu rendah adalah penurunan oksigen terlarut. Oleh karena itu, sebelum limbah diolah diperlukan pemeriksaan $\mathrm{pH}$ serta menambahkan larutan penyangga agar dicapai pH yang optimal (BPPT, 1997).

4. Karakteristik Air limbah Industri Tempe

Untuk karekteristik limbah industri tempe ada dua hal yang perlu diperhatikan yakni karekteristik fisika dan kimiawi. Karekteristik fisika meriputi padatan total, suhu, warna dan bau. Karekteristik kimiawi meliputi bahan organik, bahan anorganik dan gas. Bahan-bahan organik yang terkandung di dalam buangan industri tempe pada umumnya sangat tinggi. Senyawa-senyawa organik di dalam air buangan tersebut dapat berupa protein, karbohidrat, lemak dan minyak. Di antara senyawa-senyawa tersebut, protein yang jumlahnya paling besar yang mencapai $40 \%$ - $60 \%$ protein, $25 \%$ - 50\% karbohidrat, dan $10 \%$ lemak. Semakin lama jumlah dan jenis bahan organik ini semakin banyak, dalam hal ini akan menyulitkan pengelolaan limbah, karena beberapa zat sulit di uraikan oleh mikroorganisme di dalam air limbah tempe tersebut. Air buangan industri tempe kualitasnya bergantung dari proses yang digunakan. Apabila air prosesnya baik, maka kandungan bahan organic pada air buangannya biasanya rendah. Pada umumnya konsentrasi ion hydrogen buangan industri tempe cenderung bersifat asam. Sehingga air limbah dan bahan buangan yang dibuang ke perairan akan mengubah $\mathrm{Ph}$ air, dan dapat mengganggu kehidupan organisme air, $\mathrm{pH}$ air normal yang memenuhi syarat untuk kehidupan mempunyai $\mathrm{pH}$ berkisar antara 6,5 - 7,5. Gas - gas yang biasa ditemukan dalam limbah tempe adalah gas nitrogen (N2), oksigen (O2), hydrogen sulfide (H2S), ammonia (NH3), karbondioksida $(\mathrm{CO} 2)$ dan metana $(\mathrm{CH} 4)$. Gas-gas tersebut berasal dari dekomposisi bahan-bahan organik yang terdapat di dalam air buangan tempe. (Ilmi 2006).

Limbah cair yang dihasilkan berasal dari lokasi pemasakan kedelai, pencucian kedelai, pelralatan proses dan lantai. Karekter limbah cair yang dihasilkan berupa bahan organik padatan tersuspensi (kulit, selaput lendir dan bahan organik lain). Warna putih keruh pada air limbah berasal dari pembuangan air rendaman dan pengelupasan kulit kedelai yang masih banyak mengandung pati, juga berasal dari air bekas pencucian peralatan proses produksi, peralatan dapur dan peralatan lainnya. Bau yang timbul karena adanya aktivitas mikroorganisme yang menguraikan zat organik atau dari reaksi kimia yang terjadi dan menghasilkan gas tertentu. (Wignyanto, dkk, 2009).

Hasil penelitiana dari Tarru, dkk (2015), menunjukkan bahwa limbah pabrik tahu dan tempe sumber wangi Tallunglipu telah melewati kriteria baku mutu limbah cair bagi kegiatan industri dengan parameter fisik mempunyai kadar TSS 760.80 dan TDS 18700, parameter Kimia mempunyai kadar BOD 376.93, COD 942.32 dan pH 4.21 parameter biologis, hasil kultur bakteri Escherichia colipositif, dan berdasarkan pada baku mutu limbah cair bagi kegiatan industri sesuai dengan KEP- 51/MENLUH/10/1995, yang termasuk pada kelas I limbah yang dibuang pada pabrik.

\section{Baku Mutu Air Limbah Industri Tahu dan Tempe}

Baku mutu air limbah industri tahu dan tempe didasarkan pada Peraturan Menteri Lingkungan Hidup Republik Indonesia No.5 Tahun 2014 Tentang Baku Mutu Air Limbah, yang dapat dilihat pada Tabel 1. 
Tabel 1. Baku Mutu Air Limbah Industri Tahu dan Tempe

\begin{tabular}{|c|c|c|c|c|}
\hline \multirow{3}{*}{ Jenis Limbah } & \multicolumn{4}{|c|}{ Pengelolaan kedelai } \\
\hline & \multicolumn{2}{|c|}{ Tahu } & \multicolumn{2}{|l|}{ Tempe } \\
\hline & $\begin{array}{c}\text { Kadar *) } \\
(\mathrm{mg} / \mathrm{L})\end{array}$ & $\begin{array}{c}\text { Beban } \\
\text { (kg/ton) }\end{array}$ & $\begin{array}{c}\text { Kadar *) } \\
(\mathrm{mg} / \mathrm{L})\end{array}$ & $\begin{array}{c}\text { Kadar *) } \\
(\mathrm{mg} / \mathrm{L})\end{array}$ \\
\hline BOD & 150 & 3 & 150 & 1,5 \\
\hline COD & 300 & 6 & 300 & 3 \\
\hline TSS & 200 & 4 & 100 & 1 \\
\hline $\mathrm{Ph}$ & \multicolumn{4}{|c|}{$6-9$} \\
\hline $\begin{array}{l}\text { Kualitas air } \\
\text { limbah paling } \\
\text { tinggi (m/ton) }\end{array}$ & \multicolumn{3}{|c|}{20} & 10 \\
\hline
\end{tabular}

Keterangan :

1) *) kecuali pH

2) Satuan kuantitas air limbah adalah $m 3$ per ton bahan baku

3) Satuan beban adalah kg per ton bahan baku

Tujuan Penelitian

Penelitian ini bertujuan untuk:

1). Mengetahui kandungan limbah pabrik tahu dan tempe Rahayu yang ada Kelurahan Uner Kecamatan Kawangkoan Kabupaten Minahasa.

2). Untuk mengetahui apakah limbah pabrik tahu dan tempe Rahayu sudah melebihi baku mutu.

\section{Manfaat Penelitian}

1) Mengetahui kandungan limbah yang ada di pabrik tahu dan tempe Rahayu yang bertempat di Kelurahan Uner Kecamatan Kawangkoan Kabupaten Minahasa.

2). Penelitian ini diharapkan dapat memberikan informasi kepada pemilik pabrik tahu dan tempe Rahayu dan kepada masyaraka mengenai kandungan limbah yang ada di pabrik tahu dan tempe tersebut.

\section{METODE PENELITIAN}

\section{Tempat dan Waktu}

Penelitian ini dilaksakan selama 3 bulan yaitu pada bulan Januari 2020- Maret 2020,. Lokasi pengambilan sampel di lakukan di Pabkrik Tahu dan Tempe Rahayu di Kelurahan Uner Kecamatan Kawangkoan, kemudian dilanjutkan analisis di Laboratorium Balai Riset dan Standardisasi Industri (Baristand) Manado.

\section{Alat dan Bahan}

Alat

Alat yang akan digunakan dalam penelitian ini adalah, botol sampel, cool box, label nama, tissue, alat tulis menulis, kamera, serta alat yang digunakan untuk mengukur parameter yang di analisis.

\section{Bahan}

Bahan yang digunakan dalam penelitian ini yaitu sampel air limbah industri pabrik tahu dan tempe sebagai objek penelitian.

\section{Metode Penelitian}

Penelitian ini merupakan penelitian deskriptif dan analisi laboratorium. Pengambilan contoh air limbah di lakukan dengan metode composite sampling Pengambilan sampel dilakukan di dua tempat pertama diambil air baku yang digunakan untuk pembuatan tahu dan tempe di bak penampungan air (inlet) dan yang kedua diambil air limbah pabrik tahu dan tempe pada saluran pembuangan air limbah. Pengambilan sampel air limbah dilakukan sebanyak 3 kali dan untuk analisis di lakukan di Laboratorium Baristand untuk mendapatkan data sesuai parameter yang telah ditetapkan dalam penelitian ini.

\section{Parameter yang dianalisis}

Adapun parameter air limbah tahu dan tempe yang akan dianalisis adalah, BOD, COD, TSS, pH. didasarkan pada baku mutu Peraturan Menteri Lingkungan Hidup Republik Indonesia No.5 Tahun 2014 Tentang Baku Mutu Air Limbah.

\section{Persiapan}

\section{Prosedur Penelitian}

Kegiatan persiapan meliputi pengadaan alat dan bahan yang akan digunakan dalam penlitian dan persiapan untuk turun lapangan.

\section{Pengammbilan sampel}

Pengambilan sampel dilakukan dengan mengambil sampel air limbah menggunakan botol air mineral kemudian sampel air limbah tersebut di masukan kedalam botol sampel, jika botol sampel sudah terisi selanjutnya dimasukan kedalam cool box.

\section{Pengukuran/ Analisi laboratorium}

Sampel yang sudah diambil dibawa ke Laboratorium Baristand Manado untuk di analisis kualitas air limbah industri pabrik tahu dan tempe Rahayu di Kelurahan Uner Kecamatan Kawangkoan Kabupaten Minahasa berdasarkan parameter yang akan dianalisis (BOD, COD, TSS, $\mathrm{pH})$. 


\section{Prosedur Kerja}

\section{Prosedur kerja dilapangan}

- Mempersiapkan peralatan yaitu: botol sampel, alat tulis menulis, label nama, cool box, tissue dan kamera

- Pengambilan sampel: Pengambilan sampel dilakukan dengan mengambil sampel air limbah menggunakan botol sampelkemudian sampel air limbah tersebut di masukan kedalam botol sampel, jika botol sampel sudah terisi selanjutnya dimasukan kedalam cool box

- Kemudian sampel yang telah diambil dilapangan dibawa ke laboratorium Baristand Manado untuk dianalisis

\section{Prosedur kerja di laboratorium}

Metode yang digunakan untuk menganalisis parameter BOD, COD,TSS, $\mathrm{Ph}$, dapat dilihat pada Tabel 2.

Tabel 2. Analisis Parameter

\begin{tabular}{llr}
\hline No & Parameter & Metode analisis \\
\hline 1. & BOD & SNI 6989.59:2008 \\
2. & COD & SNI 6989.2:2009 \\
3. & TSS & SNI 6989.3:2009 \\
4. & Ph & SNI 6989.11-2009 \\
\hline
\end{tabular}

\section{Analisis Data}

Hasil analisis Laboratorium Baristand kemudian dibandingkan dengan baku mutu air limbah dalam lampiran XVIII Peraturan Menteri Lingkungan Hidup Republik Indonesia No.5 Tahun 2014 Tentang Baku Mutu Air Limbah, Baku Mutu Air Limbah Bagi Usaha Dan/Atau Kegiatan Pengolahan Kedelai.

\section{HASIL DAN PEMBAHASAN}

\section{Lokasi Penelitian dan Pengambilan Sampel}

Lokasi pengambilan sample limbah cair dilakukan pada dua tempat yang pertama diambil sampel air yang digunakan untuk proses pembuatan tahu dan tempe (inlet), yang kedua diambil sampel air limbah di saluran pembuangan air limbah (outlet). Peta likasi dapat dilihat pada gambar 1 .

\section{Hasil Analisis Parameter Biological Oxygen Demand (BOD5)}

Hasil analisis laboratorium dari limbah cair pabrik tahu dan tempe Rahayu dengan pengambilan sampel sebanyak 3 kali dapat dilihat pada Tabel 3 dan gambar 1.
Tabel 3. Nilai pengukuran parameter Biological Oxygen Demand (BOD5) pabrik tahu dan tempe Rahayu

\begin{tabular}{llcccccc}
\hline No & $\begin{array}{l}\text { Tidak } \\
\text { pengambila } \\
\text { n sampel air }\end{array}$ & $\begin{array}{c}\text { Pengambilan } \\
\text { sampel }\end{array}$ & Satuan & keterangan \\
\hline & & I & II & III & $\mathrm{mg} / \mathrm{L}$ & Memenuhi $\begin{array}{c}\text { Tidak } \\
\text { memenuhi }\end{array}$ \\
\hline 1 & Inlet & 1,7 & 1,9 & 1,8 & $\checkmark$ & & \\
2 & Outlet & 68 & 59 & 56 & $\checkmark$ & & \\
\hline
\end{tabular}

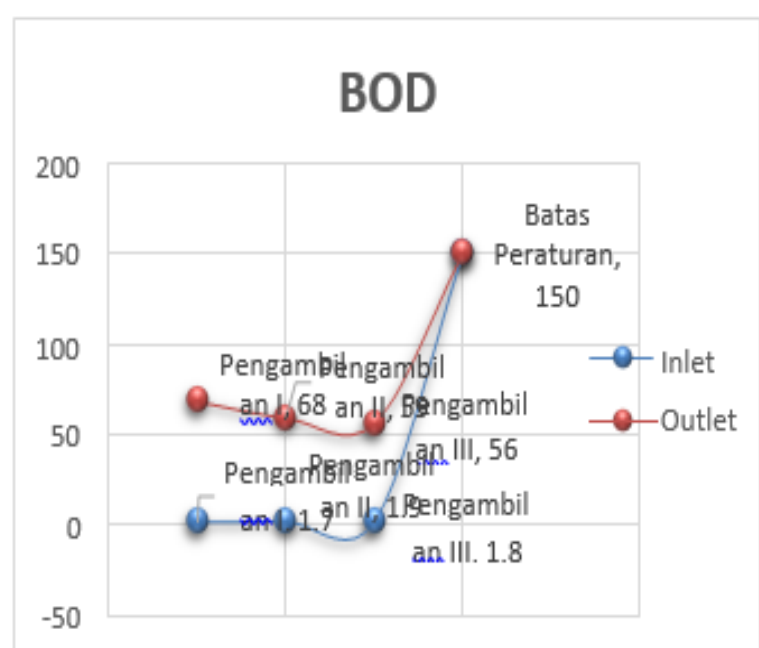

Gambar 1. hasil analisis parameter Biological Oxygen Demaind (BOD) pabrik tahu dan tempe Rahayu

Gambar 1 menunjukkan bahwa parameter BOD masih berada pada kondisi normal dan belum melewati ambang batas yang sudah di tentukan oleh pemerintah. Analisis BOD berguna untuk menentukan tingkat pencemaran bahan organik pada air limbah, jika kadar BOD terlalu tinggi maka dapat menyebabkan biota air akan mati karena asupan oksigen pada sungai akan diserap sepenuhnya oleh bakteri-bakteri yang ada untuk melarutkan bahan-bahan organik.

\section{Hasil Analisis Parameter Chemical Oxygen Demand (COD)}

Hasil analisisis laboratorium dari limbah cair pabrik tahu dan tempe Rahayu dengan pemgambilan sampel sebanyak 3 kali dapat dilihat pada Tabel 4 dan gambar 5 .

\begin{tabular}{|c|c|c|c|c|c|c|c|}
\hline \multirow[t]{2}{*}{ No } & \multirow{2}{*}{$\begin{array}{l}\text { Tidak } \\
\text { pengambilan } \\
\text { sampel air }\end{array}$} & \multicolumn{3}{|c|}{$\begin{array}{l}\text { Pengambilan } \\
\text { sampel }\end{array}$} & \multirow[t]{2}{*}{ Satuan } & \multicolumn{2}{|c|}{ Keterangan } \\
\hline & & I & II & III & & Memenuhi & $\begin{array}{c}\text { Tidak } \\
\text { memenuhi }\end{array}$ \\
\hline 1 & Inlet & 5,9 & 5,8 & 6,0 & $\mathrm{mg} / \mathrm{L}$ & $\checkmark$ & \\
\hline 2 & Outlet & 195 & 157 & 154 & & & \\
\hline
\end{tabular}




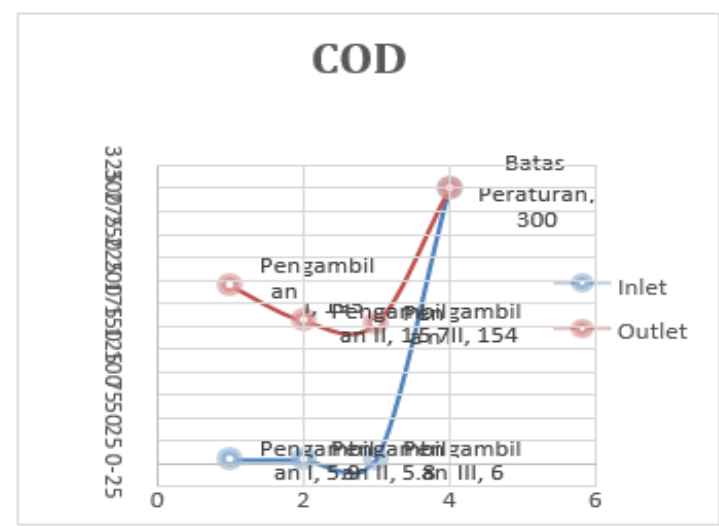

Gambar 2. Hasil analisis parameter Chemical Oxygen Demand (COD) pabrik tahu dan tempe Rahayu

Berdasarkan Tabel 4 dan gambar 2, dapat dilihat bahwa hasil analisis nilai COD masi berada dalam kondisi baik dan belum melewati baku mutu yang sudah ditetapkan oleh pemerintah. Jika nilai parameter COD pada air limbah tinggi dapat mengakibatkan tidak adanya kehidupan biota air.

\section{Hasil Analisis Parameter}

\section{Total Suspended Solid (TSS)}

Hasil analisisis laboratorium parameter TSS dari limbah cair pabrik tahu dan tempe Rahayu dengan pemgambilan sampel sebanyak 3 kali dapat dilihat pada Tabel 5 dan gambar 3 .

Tabel 5. Nilai Total Suspended Solid (TSS) pabrik

\begin{tabular}{llcccccc}
\multicolumn{8}{c}{ tahu dan tempe Rahayu } \\
\hline No & $\begin{array}{l}\text { Tidak } \\
\text { pengambilan } \\
\text { sampel air }\end{array}$ & $\begin{array}{c}\text { Pengambilan } \\
\text { sampel }\end{array}$ & Satuan & & Keterangan \\
\hline & & & & & & \\
\hline 1 & I & II & III & & Memenuhi & $\begin{array}{c}\text { Tidak } \\
\text { memenuhi }\end{array}$ \\
\hline 2 & Outlet & 1,2 & 1,3 & 1,2 & $\mathrm{mg} / \mathrm{L}$ & $\checkmark$ & \\
\hline
\end{tabular}

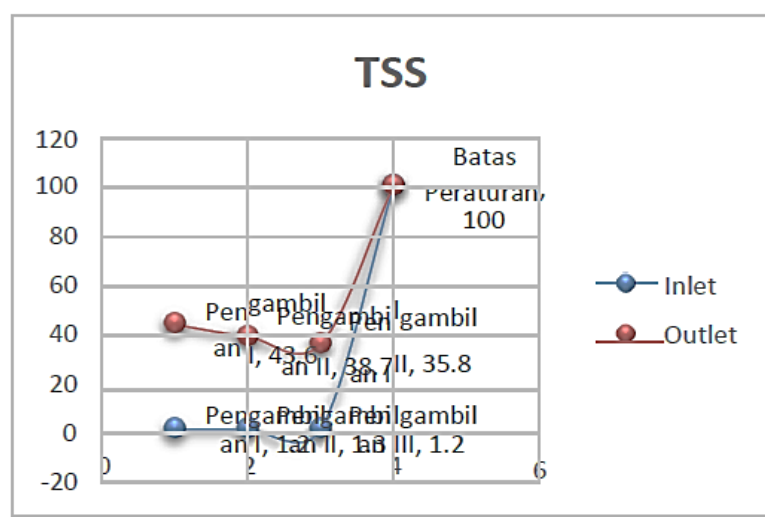

Gambar 3. Hasil analisis parameter Nilai Total Suspended Solid (TSS) pabrik tahu dan tempe Rahayu
Gambar 3 menunjukkan tingkat pembatas parameter TSS yang masi berada pada kondisi normal dan belum melewati baku mutu air limbah yang sudah ditetapkan oleh pemerintah, ini dikarenakan pada bak aqualisasi sudah di pasang alat penyaring sehingga padatan-padatan hasil pembuatan tahu dan tempe tertahan pada alat penyaring tersebut.

Hasil Analisis Parameter Derajat Keasaman (pH)

Hasil analisis laboratorium parameter $\mathrm{pH}$ yang didapat dari limbah cair pabrik tahu dan tempe Rahayu dengan pemgambilan sampel sebanyak 3 kali dapat dilihat pada Tabel 6 dan gambar 4.

Tabel 6. Nilai Derajat Keasamaan (pH) pabrik tahu dan tempe Rahayu

\begin{tabular}{|c|c|c|c|c|c|c|c|}
\hline \multirow[t]{2}{*}{ No } & \multirow{2}{*}{$\begin{array}{l}\text { Tidak } \\
\text { pengambilan } \\
\text { sampel air }\end{array}$} & \multicolumn{3}{|c|}{ Pengambilan sampel } & \multirow[t]{2}{*}{ Satuan } & \multicolumn{2}{|c|}{ Keterangan } \\
\hline & & I & II & III & & Memenuhi & $\begin{array}{c}\text { Tidak } \\
\text { memenuhi }\end{array}$ \\
\hline 1 & Inlet & 6,70 & 6,73 & 5,72 & - & & $\checkmark$ \\
\hline 2 & Outlet & 5,72 & 5,83 & 4,80 & & & \\
\hline
\end{tabular}

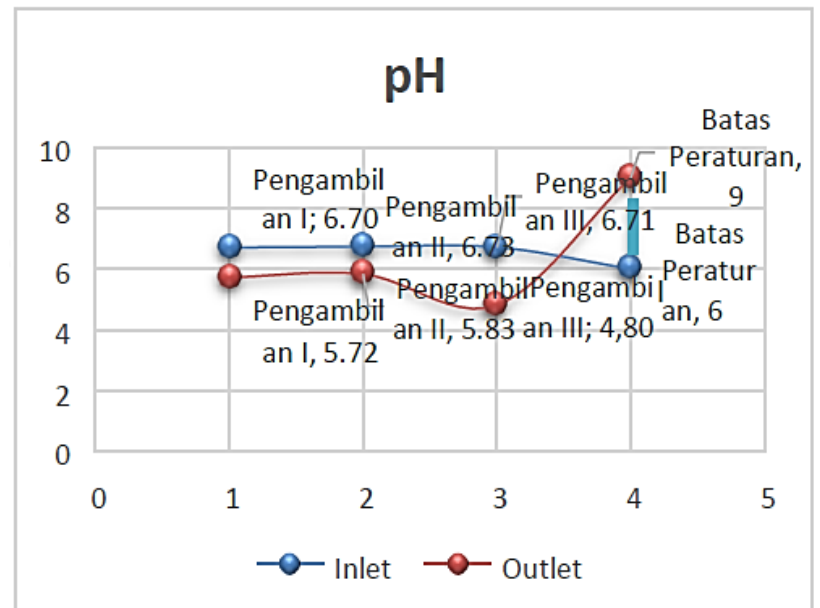

Gambar 4. Hasil analisis parameter nilai $\mathrm{pH}$ pabrik tahu dan tempe Rahayu

Berdasarkan Tabel 6 dan gambar 4 dapat dilihat bahwa parameter $\mathrm{pH}$ dalam kondisi yang tidak baik dan tidak sesuai dengan baku mutu yang di terapkan oleh pemerintah. Nilai $\mathrm{Ph}$ yang ada pada limbah cair pabrik tahu dan tempe Rahayu bersifat asam ini dikarenakan limbah cair tahu mengandung asam cuka sisa dari proses pengumpalan dan perendaman tahu dan tempe sehingga limbah cairnya bersifat asam. 


\section{KESIMPULAN DAN SARAN}

\section{Kesimpulan}

Berdasarkan hasil penelitian yang dilakukan dapat disimpulkan bahwa

- Kandungan limbah cair industri tahu dan tempe Rahayu yang ada di Kelurahan Uner Kecamatan Kawangkoan Kabupaten Minahasa adalah sebagai berikut, parameter BOD (inlet $1.7,1.9,1.8$ dan outlet $68,59,56$ ), COD (inlet $5.9,5.8,6.0$ dan outlet $95,157,154$ ), TSS (inlet $1.2,1.3,1.2$ dan outlet $43.6,38.7,35.8)$, dan $\mathrm{pH}$ (inlet $6.70,6.73,6.71$ dan outlet 5.72, 5.83, 4.80)

- Kulitas limbah cair industri tahu dan tempe Rahayu berdasarkan analisis parameter BOD, COD, dan TSS yang telah dianalisis adalah sesuai dan belum melewati baku mutu yang sudah di tetapkan oleh Pemerintah sedangkan untuk parameter $\mathrm{pH}$ tidak sesuai dan sudah melewati baku mutu yang di tetapkan oleh Pemerintah.

\section{Saran}

Perlu dilakukan penelitian lanjutan tentang bagaimana menurunkan kadar $\mathrm{Ph}$ limbah air pabrik tahu dan tempe Rahayu.

\section{DAFTAR PUSTAKA}

Agung, T R. \& Hanry S W. (2012). Pengolahan Limbah Industri Tahu dengan Menggunakan Teknologi Plasma. Jurnal Ilmiah Teknik Lingkungan. 02, 19-28.

Anonim, 2017, Teknologi Pengolahan Limbah Tahu Dan Tempe Dengan Proses Biofilter Anaerob Dan Aerob, rinideviantialit.blogspot.com/2017/01/. Diakses 10-02-2020.
BPPT, 1997. Teknologi Pengolahan Limbah TahuTempe Dengan Proses Biofilter Anaerob dan Aerob.http://www.enviro. bppt.go.id/Kel-1/ Eckenfelder, W.W., 1989, Industrial Water Pollution Control, 2nd ed., Mc Graw Hill Inc.,New York.

Effendi, H. 2003. Telaah Kualitas Air. Yogyakarta: Kanisius.

Ilmi, 2016 "Tugas Pengolahan Limbah Tempe", dalam https://www.scribd. com /doc/3070 50050, diakses tanggal 25 February 2020, pukul 11.00 WITA.

Kaswinarni, F. 2007. "Kajian Teknis Pengolahan Limbah Padat dan Cair Industri Tahu". Thesis. Semarang: Program Studi Ilmu Lingkungan Universitas Diponegoro.

Lilis, 2008, Pengolahan limbah Cair Tempe dengan Menggunakan Filter Karbon Aktif,,jurnal Ilmiah Satya Negara. 4 (2): 4250 .

Metcalf, dan Eddy. 2003. Wastewater Engineering Treatment and Reuse. Fourth Edition. International edition. New York : McGrawHill.

Peraturan Menteri Lingkungan Hidup Republik Indonesia No.5 Tahun 2014 Tentang Baku Mutu Air Limbah. Diakses Pada Tanggal 6 November 2019.

Tarru. R. O, Tarru. H. E, Rapang. D. 2015. Analisis Dampak Buangan Limbah Cair Pada Aliran Sungai. SA' DAN ( Strategi Kasus Pabrik Tahu Dan Tempe Sumber Wangi Tallunglipu, 6 (1): 14-17.

Yahya V.J, 2016, Pengolaham Limbah Industri Tahu,vandajulita.blogspot.com/2016/01/pe ngolaham-limbah-industri-tahu.html. 